\title{
Treatment of Fizzy Drink Factory Wastewaters by Microalgae and Evaluation of Algae Oil for Biofuel Production
}

\author{
Togayhan Kutluk ${ }^{1}$, Nurcan Kapucu ${ }^{2 *}$ \\ ${ }^{1}$ Kocaeli University, Faculty of Engineering, Chemical Engineering Department, Kocaeli, Turkey (ORCID: 0000-0001-7249-9902) \\ ${ }^{2}$ Kocaeli University, Faculty of Engineering, Chemical Engineering Department, Kocaeli, Turkey (ORCID:0000-0002-5542-7816)
}

(First received 4 Şubat 2020 and in final form 31 Mart 2020)

(DOI: 10.31590/ejosat.684478)

ATIF/REFERENCE: Kutluk, T. \& Kapucu, N. (2020). Treatment of Fizzy Drink Factory Wastewaters by Microalgae and Evaluation of Algae Oil for Biofuel Production. European Journal of Science and Technology, (18), 879-884.

\begin{abstract}
As a result of city, industrial and agricultural activities, a large amount of wastewater is generated every year. The wastewater generated must be treated. When the nitrogen concentration in wastewater reaches more than $1.9 \mathrm{mg} / \mathrm{L}$, favorable environmental conditions are provided for the microalgae to multiply. In the presence of microalgae in wastewater treatment technologies, treatment has gained importance in recent years and has become a more environmentally-friendly alternative in treatment. Research on the availability of biomass as a source of raw materials in the production of alternative energy sources is increasingly important. In this paper, Chlorella variabilis microalgae growth, lipid productivity and nutrient removal in wastewater media were investigated. Before the inoculation of microalgae, wastewater was centrifuged at $4000 \mathrm{rpm}$ to remove the solid particles and was diluted with tap water in different ratios $(0-$ $40 \%$ ). Wastewaters were inoculated with Chlorella variabilis in $250 \mathrm{~mL}$ open flasks in a $200 \mathrm{rpm}$ shaking incubator for a month at 27 ${ }^{\circ} \mathrm{C}$. After incubation maximum cell concentration $(\mathrm{Xmax}=1.03 \mathrm{gdw} / \mathrm{L})$, growth rate $\left(\mu \max =4.0 \times 10^{-3} \mathrm{~h}^{-1}\right)$, and doubling time $(173 \mathrm{~h})$ of the microalgae were reached in $40 \%$ diluted medium. Fat content $(21 \%)$ and lipid productivity $\left(6 \times 10^{-3} \mathrm{~g} / \mathrm{L} . \mathrm{d}\right)$ were determined concurrently for $20 \%$ diluted media. It was determined that microalgae lipids were rich in oleic (C18:1, 38\%) and linolenic acid (C18:3, $35 \%$ ). The efficiency of COD (Chemical oxygen demand) and total phosphor removal in the presence of microalgae had been almost $60 \%$ and $77 \%$ respectively. According to the experimental results, the treatment of wastewater in the presence of microalgae is promising for future applications.
\end{abstract}

Keywords: Algae oil, Fizzy drink, Microalgae, Wastewater

\section{Gazlı İçecek Endüstri Atık Suyunun Mikroalg ile Muamelesi ve Mikroalgal Yağın Biyoyakıt Üretimi için Değerlendirilmesi}

Öz

Şehir, sanayi ve tarım faaliyetleri sonucunda her yıl büyük miktarlarda atık su üretilmektedir. Üretilen atık sular arıtılmalıdır. Atık suda varolan azot derişimi 1,9 mg/L değerinin üzerine çıktığında, mikroalglerin çoğalması için uygun çevresel koşullar sağlanır. Atıksu arıtma teknolojilerinde mikroalg varlığında arıtma, son yıllarda önem kazanmış ve arıtımda daha çevre dostu bir alternatif haline gelmiştir. Alternatif enerji kaynaklarının üretiminde hammadde kaynağı olarak biyokütlenin bulunabilirliği üzerine araştırmalar giderek önem kazanmaktadır. Bu çalışmada, atık su ortamlarında Chlorella variabilis mikroalg büyümesi, lipit üretkenliği ve nütrient giderimi araştırılmıştır. Mikroalglerin aşılanmasından önce atık su, katı parçacıkların uzaklaştırılması amacıyla 4000 rpm koşulunda santrifüjlenmiş ve farklı oranlarda (\%0-40) musluk suyu ile seyreltilmiştir. Farklı oranlarda seyreltilmiş olan atıksular, $250 \mathrm{~mL}$ hacimli ağzı açık olan şişeler içinde Chlorella variabilis mikroalgi ile aşılanmış, $27{ }^{\circ} \mathrm{C}$ sıcaklık ve 200 rpm çalkalama hızına sahip olan inkübatörde, bir ay süre boyunca inkübe edilmiştir. İnkübasyon sonucunda maksimum mikroalg derişimi $(\mathrm{Xmax}=1.03 \mathrm{gdw} / \mathrm{L})$, hücre büyüme miktarı $\left(\mu \max =4.0 \times 10^{-3} \mathrm{~h}^{-1}\right)$ ve mikroalglerin ikiye katlanma süresine (173 saat) \% 40 oranında musluk suyu ile seyreltilmiş olan atık su ortamında ulaşılmıştır. Mikroalgal biyokütleden elde edilen lipid yăg içeriği (\% 21) ve lipit üretkenliği (6x10 $\left.{ }^{-3} \mathrm{~g} / \mathrm{L} . \mathrm{d}\right), \%$ 20 oranında seyreltilmiş atık su ortamı için eşzamanlı olarak belirlenmiştir. Mikroalg lipidlerinin oleik asit (C18:1, \% 38) ve linolenik asit (C18:3, \% 35) bakımından zengin olduğu tesbit edilmiştir. Mikroalglerin varlığında Kimyasal Oksijen İhtiyacı (KOİ) ve toplam fosfor giderimi etkinliği sırasıyla, yaklaşık olarak \% 60 ve \% 77 değerinde olmuştur. Deney sonuçlarına göre, atık suyun mikroalglerin varlığında arıtımı gelecekteki uygulamalar için umut vericidir.

Anahtar Kelimeler: Alg yağı, Atık su, Gazlı içecek, Mikroalg

* Corresponding Author: Kocaeli University, Faculty of Engineering, Chemical Engineering Department, Kocaeli, Turkey, ORCID:0000-0002-55427816,nurcan.kapucu@kocaeli.edu.tr 


\section{Introduction}

The rapid increase in the human population has led to industrial development, which represents a vital factor in the economic development of countries. In research conducted; It is stated that the increase in wastewater in developing countries is related to population growth. The wastewater from agricultural and industrial sources has significant organic matter content. Some wastewater also contains oil, grease, heavy metals and toxic chemicals. Most of the industrial wastewater needs to be treated to protect human health from environmental pollution and to ensure the safety of water resources (Girard et al, 2014). Effective treatment is very costly to relevant industry organizations. Therefore, in the treatment of such wastes, which is the most important problem of many industrial organizations today; Extensive scientific studies are carried out for the treatment processes that will provide convenience in economically cheap and environmentally friendly applications. Three types of methods are generally used for the treatment of wastewater; physical treatment, chemical treatment, and biological treatment. Biological treatment is an environmentally friendly process according to other methods. The legal regulations of governments today and the development of more environmentally friendly processes have increased the importance of biological treatment ( $\mathrm{Li}$ et al, 2013). Therefore, industrial wastewater treatment by microalgae has gained great importance recently in the reduction of high organic compounds and heavy metals. At the same time, this technology is also capable of producing biofuels as an alternative energy source in the form of biodiesel, bioethanol, and biogas. Microalgae are used in wastewater treatment as part of new breeding technology compared to conventional wastewater treatment processes (Abinandan \& Shanthakumar, 2015). Microalgae can be grown in industrial wastewater. Industrial wastewater contains sufficient amounts of phosphorus and ammonia necessary for the growth of the microorganism. Although some wastewater has a high content of heavy metals, and also this kind of metals has negative effects on microalgae growth, they can be removed by pretreatments (dilution, precipitation, etc.) in wastewater. Some studies are investigating the treatment of different industrial wastewater with different types of microalgae in the literature. In their study, $\mathrm{Wu}$ et al. investigated the possibility of microalgae removal of nitrogen and phosphorus from industrial wastewater. Chlamydomonas cells removed approximately $95 \%$ of the ammonium from the wastewater in the second day of treatment. Ammonium removal was determined to be $19.2 \mathrm{mg} / \mathrm{L}$.d. After 10 days of purification, approximately $33 \%$ of the phosphorus was removed (Wu et al, 2012). Hongyang et al. have determined that COD is eliminated in approximately $70 \%$ yield in the presence of microalgae (C. pyrenoidosa) of soybean wastewater. At the same time, 90\% ammonia removal was achieved by treatment of pig farm wastewater in the presence of the same type of microalgae (Hongyang et al, 2011). Li et al. investigated the treatment of citric acid production plant wastewater in the presence of C. vulgaris C9-JN2010 type microalgae. After 20 days of treatment, 90\% COD provided nitrogen and phosphorus removal. Also, 95\% of the total organic carbon (TOC) contained in the wastewater has been eliminated ( $\mathrm{Li}$ et al, 2013). When the literature is examined, there is no study investigating the treatment potential of wastewater in the presence of Chlorella variabilis microalgae. In this study, Chlorella variabilis microalgae growth, lipid productivity and nutrient removal in wastewater media were investigated. At the same time, the availability of microalgae oil as a raw material for biofuel production was evaluated.

\section{Material and Method}

\subsection{Materials}

The wastewater is supplied from a local fizzy drink factory. Microalgae specie (Chlorella variabilis) was donated from the Department of Molecular Biology and Genetics of Istanbul Civilization University. Chlorella variabilis strain stock culture was cultivated in Blue Green Medium (BG 11) in tap water. The chemical composition of this medium was (g/L); $\mathrm{NaNO}_{3}, 1.5 ; \mathrm{KH}_{2} \mathrm{PO}_{4}, 0.04 ; \mathrm{MgSO}_{4} .7 \mathrm{H}_{2} \mathrm{O}$, $0.075 ; \mathrm{CaCl}_{2} .2 \mathrm{H}_{2} \mathrm{O}, 0.036 ; \mathrm{H}_{3} \mathrm{BO}_{3} 0.0029 ; \mathrm{Na}_{2} \mathrm{CO}_{3}, 0.02 ; \mathrm{Fe}(\mathrm{III})$ citrate, 0.006 ; citric acid 0.006 . The chemicals used in the study were in analytical purity. Osram brand LED with the light intensity value of $3 \mathrm{Klux}$, were used for the light source.

\subsection{Microalgae cultivation in wastewater media}

Microalgae strain was cultured at INNOVA 40 shaker incubator, at $27{ }^{\circ} \mathrm{C} \mathrm{rpm}$ and $200 \mathrm{rpm}$ shaking rate. In $250 \mathrm{ml}$ flasks, $6 \mathrm{ml}$ of Chlorella variabilis was inoculated into $200 \mathrm{ml}$ of diluted wastewater. The solid impurities were precipitated and removed by centrifugation at $4000 \mathrm{rpm}$ for 20 minutes from wastewater before using as culture media. Then it was diluted with tap water in different ratios $(0-10-20-30-40-50 \%)$. The $\mathrm{pH}$ values of the culture media were initially measured as approximately 6.05 . The cultures were aerated by naturally from the surface.

\subsection{Determination of cell concentration}

The cell concentration and growth was determined spectrophotometrically at $680 \mathrm{~nm}$ using Jenway 6800 UV Vis. Spectrophotometer. The growth rates of cultures were determined by using equation 1:

$$
\mu_{\max }=\frac{\ln \left(x_{2}-x_{1}\right)}{t_{2}-t_{1}}
$$

where $\mathrm{X}$ is the cell concentration $(\mathrm{g} / \mathrm{L}), \mathrm{t}$ is the time $(\mathrm{h})$. The maximum growth rate $(\mu \mathrm{max})$ is the growth rate obtained during the logarithmic phase of the growth plots. The time required to double the microbial mass $\left(\tau_{\mathrm{d}}\right)$ is given by equation 2 : 


$$
\tau_{d}=\frac{\ln 2}{\mu_{\max }}=\frac{0.693}{\mu_{\max }}
$$

After the treatment, microalgae were harvested by centrifugation at $5000 \mathrm{rpm}$ for five minutes.

\subsection{Determination of lipid contents}

The lipid content of the microorganism was analyzed according to the method of Dyer (Bligh \& Dyer,1959) . The lipid productivity of the microorganism (g/L.day) is called grams of lipid, which can be produced per day per liter. The lipid productivity of the Chlorella variabilis was calculated as a result of thirty-three days of incubation.

\subsection{Determination of COD and total phosphor}

After treatment, Chemical Oxygen Demand (COD) and total phosphor contents in wastewater were determined by using the UV-VIS spectroscopic technique, in the presence of Hach Lange LCK kits 514 and 349 respectively. COD removal was determined by using equation 3 :

$$
\text { COD Removal } \%=\frac{C O D_{o}-C O D}{C O D_{0}}
$$

where CODo is pre-treatment COD value and COD is post-treatment COD value. The same calculation is valid for total phosphorus removal.

\subsection{Determination of fatty acid composition}

The fatty acid composition was determined using a GC 7820 Agilent gas chromatograph equipped with a flame ionization detector (FID) and a $30 \mathrm{~m} \times 320 \mu \mathrm{m} \times 0.25 \mu \mathrm{m}$ capillary column (CARBOWAX 20M) according to the Davit et al. Agilent Application note (David et al, 2005). The composition of the fatty acid was determined by comparing the peak area of the fatty acid to the total peak areas of the fatty acids.

Sample preparation:0,1 gr of oil dissolved in $\mathrm{n}$-heptane with $\% 99$ purity and mixture adding $0,1 \mathrm{~N} \mathrm{KOH}$ solution for obtaining derivated fatty acids methyl esters. The injection volume was $1 \mu 1$ into the GC. No internal standard was used.

Oven conditions: After waiting for 1 minute at $50^{\circ} \mathrm{C}$, it was reached at $200^{\circ} \mathrm{C}$ with an increase of $25^{\circ} \mathrm{C}$ per minute, and $230^{\circ} \mathrm{C}$ with an increase of $3^{\circ} \mathrm{C}$ per minute and kept for 18 minutes at this temperature. Then, it increased to $280^{\circ} \mathrm{C}$ with an increase of $40^{\circ} \mathrm{C}$ per minute and the analysis was terminated by waiting for 3 minutes at this temperature. The total analysis time takes 35 minutes. Helium was used as a carrier gas.

\section{Results and Discussion}

Microalgae make photosynthesis by using light. The light distribution in the growth environment is desired to be good. Wastewater is often dirty dark color. On the other hand, the higher opacity of wastewater occasioned stress conditions, limiting light penetration and thus directly affecting photosynthesis (Magri et al, 2013; Lavine et al, 2011). The effect of different dilution rates of wastewater medium on the growth of Chlorella variabilis microalgae are shown in Figure 1. Microalgae growth was observed in all culture media, and the highest cell concentration $(1.03 \mathrm{~g} / \mathrm{L})$ was reached in undiluted culture media. Figures2 shows the $\mathrm{pH}$ changes in these culture media. The $\mathrm{pH}$ increases when the microalgae use nitrate in the culture medium. Initially 6 , the $\mathrm{pH}$ value increased up to $236^{\text {th }}$ hour and reached to 9.5 , then remained stable around this value until the end of the runs.

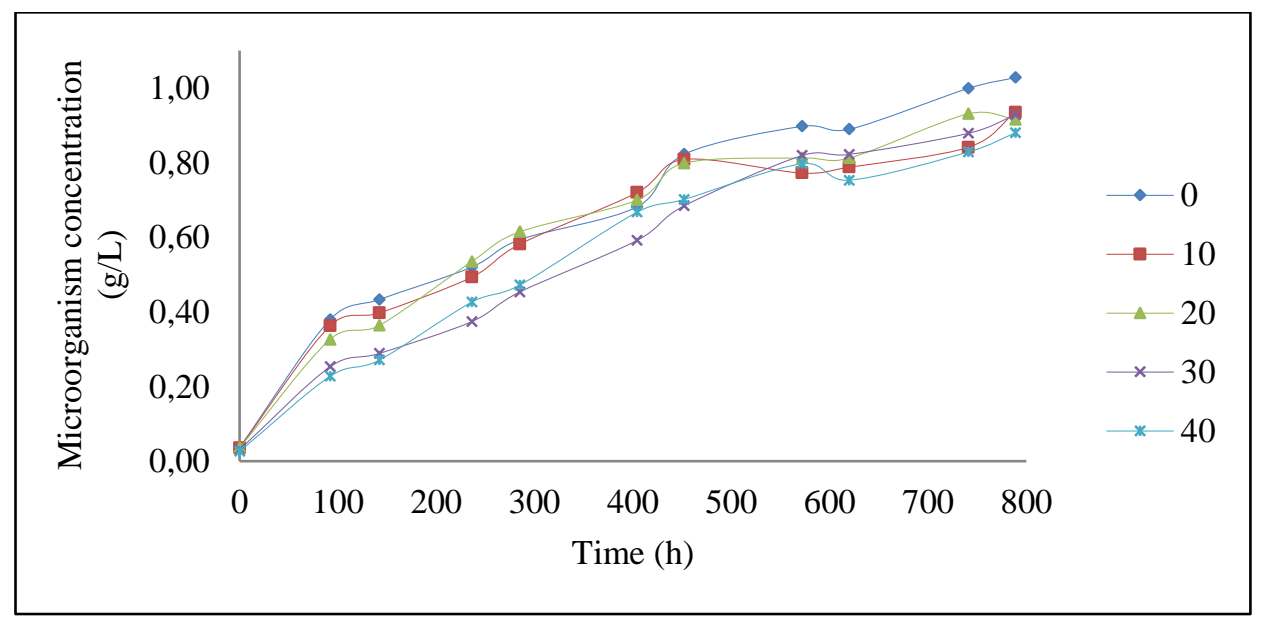

Figure 1. Microorganism growth curve under different dilution rates 


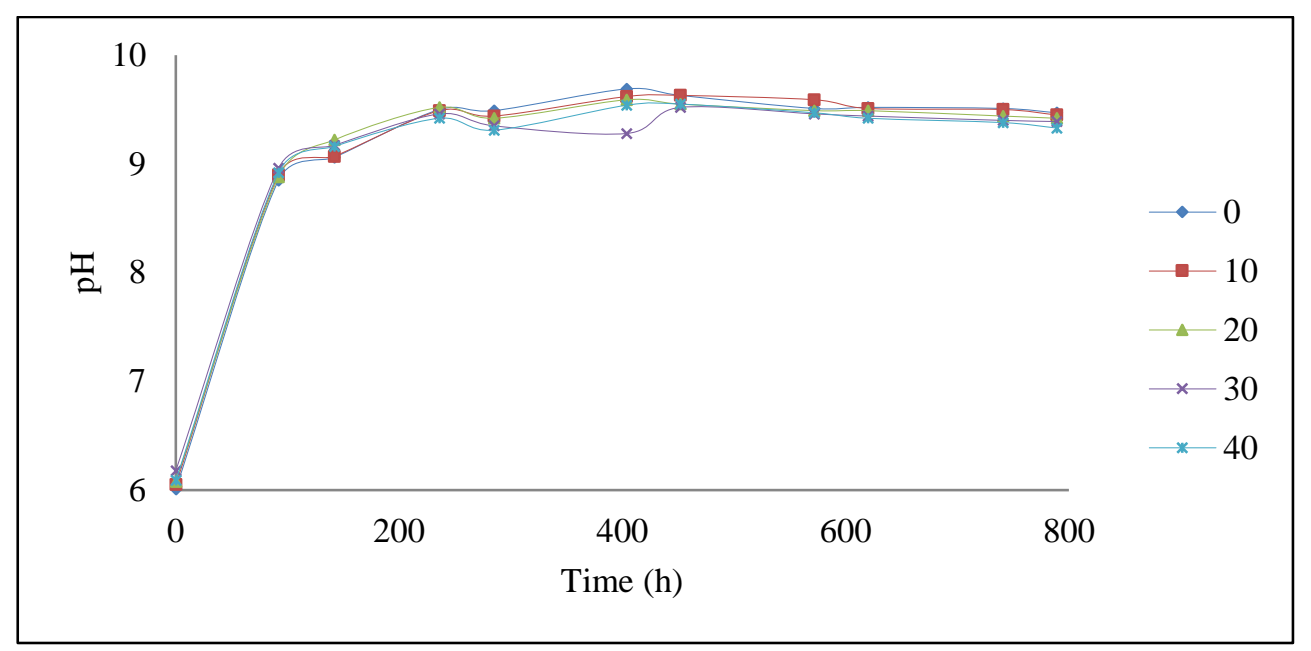

Figure 2. $p H$ changes in cultures under different dilution rates

Table 1 shows that the properties of microorganisms grown at different dilution rates in wastewater media. The maximum growth rate $\left(\mu \max =0.004 \mathrm{~h}^{-1}\right)$ and the doubling time $(173$ hours $)$ were obtained a $30 \%$ dilution rate. The highest lipid content $(21 \%)$ and lipid productivity $\left(6 \times 10^{-3} \mathrm{~g} / \mathrm{L} . \mathrm{d}\right)$ were achieved in the presence of $20 \%$ dilution in wastewater. According to the experimental results, while dilution did not significantly affect proliferation, it affected lipid content and lipid productivity. In this study, for the first time in the literature, wastewater treatment potential and also lipid productivity of Chlorella variabilis microalgae were investigated.

Table 1. Obtained experimental data in wastewater microalgal treatment

\begin{tabular}{cccccc}
\hline Dilution rate & $\mathbf{X}_{\max }$ & $\boldsymbol{\mu}_{\max }$ & $\begin{array}{c}\text { Doubling } \\
\text { time }\end{array}$ & $\begin{array}{c}\text { Lipid } \\
\text { content }\end{array}$ & $\begin{array}{c}\text { Lipid } \\
\text { productivity }\end{array}$ \\
$\mathbf{( \% )}$ & $\mathbf{( g / \mathbf { L } )}$ & $\mathbf{h}^{-\mathbf{1}}$ & $\mathbf{( h )}$ & $\mathbf{( \% )}$ & $\mathbf{g} / \mathbf{L . d x 1 0} \mathbf{d r}^{-3}$ \\
\hline 0 & 1.03 & 0.0026 & 266 & 3.70 & 1 \\
10 & 0.93 & 0.0034 & 203 & 11.00 & 3 \\
20 & 0.92 & 0.0029 & 239 & 21.00 & 6 \\
30 & 0.93 & 0.0040 & 173 & 14.23 & 4 \\
40 & 0.88 & 0.0030 & 181 & 14.60 & 3 \\
\hline
\end{tabular}

The fatty acid profile of the microalgal lipid, cetane number of these fatty acids and their usability as a raw material in biodiesel production was also investigated. The fatty acid composition of Chlorella variabilis grown at $20 \%$ diluted media is given in Table 2 . It was determined that microalgae lipids were rich in oleic $(\mathrm{C} 18: 1,38 \%)$ and linolenic acid $(\mathrm{C} 18: 3,35 \%)$. Cetane number is an expression of fuel ignition quality. Fuel with a high cetane number can easily ignite and burn quickly. The cetane number of biodiesel is higher than that of diesel fuel and the number of cetane increases as the number of carbon of fatty acids increases (Klopfenstein, 1985; Gopinath ET AL, 2009). The amount of cetane in biodiesel varies between 55 and 75 . The cetane number of oil obtained from microalgae was calculated as 56.2 bu using equation 4 . It can be said that it is suitable as a raw material for biodiesel production.

$$
C N=58.1+\frac{2.8(n-8)}{2}-15.9 \times \text { number of double bonds }
$$

where $\mathrm{n}$ is carbon $(\mathrm{C})$ number. 
Table 2. Fatty acid composition of Chlorella variabilis grown at $20 \%$ diluted media

\begin{tabular}{cc}
\hline Fatty acid & Composition \% \\
\hline C16:0 Palmitic & 16.41 \\
C17:0 Margaric & 2.02 \\
C17:1Heptadeconaic & 4.98 \\
C18:0 Stearic & 2.75 \\
C18:1 Oleic & 37.24 \\
C18:2 Linoleic & 1.05 \\
C18:3 Linolenic & 34.63 \\
C20:1Eisioneic & 0.92 \\
\hline
\end{tabular}

COD $(\mathrm{mg} / \mathrm{L})$ and total phosphor $(\mathrm{mg} / \mathrm{L})$ removal achieved at the end of 33 days of treatment is illustrated in Table 3, and Table 4, respectively. The efficiency of COD and total phosphor removal in the presence of microalgae had been almost $60 \%$, and $77 \%$ respectively. In literature, after 10 days of industrial wastewater purification, approximately $33 \%$ of the phosphorus was removed using Chlamydomonas cells [4]. In another study, COD is eliminated in approximately $70 \%$ yield in the presence of microalgae $(C$. pyrenoidosa) of soybean wastewater [5]. It was investigated that the COD removal of citric acid production plant wastewater in the presence of C. vulgaris C9-JN2010 type microalgae, and it was found to be 90\%, after 20 days of treatment (Li et al, 2013).

Table 3. Concentrations $(\mathrm{mg} / \mathrm{L})$ COD before and after microalgae treatment, and COD removal

\begin{tabular}{cccc}
\hline Dilution \% & COD $_{\mathbf{0}}(\mathbf{m g} / \mathbf{L})$ & COD & COD removal \% \\
\hline 0 & & & 62 \\
10 & 4250 & 1620 & 59 \\
20 & 3825 & 1570 & 52 \\
30 & 3400 & 1600 & 49 \\
40 & 2975 & 1530 & 42 \\
\hline
\end{tabular}

Table 4.Concentrations $(\mathrm{mg} / \mathrm{L})$ total phosphor before and after microalgae treatment and total phosphor removal

\begin{tabular}{cccc}
\hline Dilution \% & $\mathbf{P}_{\mathbf{o}}(\mathbf{m g} / \mathbf{L})$ & $\mathbf{P}(\mathbf{m g} / \mathbf{L})$ & P removal \% \\
\hline 0 & 14.50 & 3.38 & 77 \\
10 & 13.05 & 3.00 & 77 \\
20 & 11.60 & 3.18 & 73 \\
30 & 10.15 & 2.62 & 74 \\
40 & 8.70 & 2.32 & 73 \\
\hline
\end{tabular}

\section{Conclusions and Recommendations}

. In this study treatment ability and lipid productivity of microalgae Chlorella variabilis in fizzy drink wastewater media have been investigated. After treatment, COD and total phosphor removal had been almost $60 \%$ and $77 \%$, respectively, in the presence of Chlorella variabilis. Also, up to $22 \%$ of microalgal lipids by dry weight of microalgae were obtained at the end of the treatment. From the obtained experimental data, it is possible to draw some conclusions on this study;

$\checkmark$ A certain effect of the dilution in the wastewater media for microalgal treatment was not observed on growth, but it affected lipid content and lipid productivity. Microalgae are useful for wastewater treatment.

$\checkmark$ Obtained lipids after treatment from microalgae paste are promising to use as raw materials in the production of biodiesel according to the cetane number of Chlorella variabilis oil. 


\section{Acknowledge}

The authors thank the Pakmaya Environmental Laboratory for COD and total phosphorus analysis.

\section{References}

Abinandan, S., Shanthakumar, S. (2015). Challenges and opportunities in application of microalgae (ChloropHyta) for wastewater treatment: A review. Renewable and Sustainable Energy Reviews, 52, 123-132.

Bligh, E.G., Dyer, W.J. (1959). A rapid method for total lipid extraction and purification. Canadian Journal of Biochemistry and Physiology, 37, 911-917.

David, F, Sandra P, Vickers, A.K. (2005). Column selection for the analysis of fatty acids methyl esters. Application Agilent Technolojies Inc.

Girard, J-M., Roy, M-L., Hafsa, B.M., Gagnon, J., Faucheux, N., Heitz, M., Tremblay, R., Deschenes, J-S. (2014). Mixotrophic cultivation of green microalgae Scenedesmus obliquus on cheese whey permeate for biodiesel production. Algal Research, 5, 241248.

Gopinath, A, Puhan, S, Nagarajan, G. (2009). Relating the cetane number of biodiesel fuels to their fatty acid composition: A critical study. Proceedings of the Institution of Mechanical Engineers, Part D: Journal of Automobile Engineering, 223, 565-583.

Hongyang, S., Yalei, Z., Chunmin, Z., Xuefei, Z., Jinpeng, L. (2011), Cultivation of Chlorella pyrenoidosa in soybean processing wastewater. Bioresource Technology, 102(21), 9884-9890.

Klopfenstein, W.E. (1985). Effect of molecular weights of fatty acid esters on cetane numbers as diesel fuel. Journal of American Oil Chemical Socitey, 62, 1029- 1031.

Levine, R. B., Costanza-Robinson, M.S., Spatafora, G.A. (2011). Neochloris oleoabundans grown on anaerobically digested dairy manure for concomitant nutrient removal and biodiesel feedstock production. Biomass and Bioenergy, 351, 40-49.

Li, C., Yang, H., Xia, X., Li, Y., Chen, L., Zhang, M., Zhang, M., Wang, W. (2013). High efficient treatment of citric acid effluent by Chlorella vulgaris and potential biomass utilization. Bioresource Technology 127, 248-255.

Magri, A., Beline, F., Dabert, F. (2013). Feasibility and interest of the anammox process as the treatment alternative for anaerobic digester supernatants in manure processing: An overview. Journal of Environmental Management, 131, 170-184.

Wu, L.F., Chen, P.C., Huang, A.P., Lee, C.M. (2012). The feasibility of biodiesel production by microalgae using industrial wastewater. Bioresource Technology, 113,14-18. 